\title{
Bacillus subtilis Smc condenses chromosomes in a heterologous cell system, which is down-regulated by ScpAB
}

\author{
Tobias Knust ${ }^{1}$ and Peter L. Graumann ${ }^{2,3^{*}}$ (1)
}

\begin{abstract}
Objective: Structural maintenance of chromosomes (SMC) proteins are key players in chromosome dynamics in all types of organisms. The so-called condensin subfamily is essential for chromosome condensation in eukaryotic cells, as is the bacterial SMC complex (called MukBEF in Escherichia coli). We expressed the Bacillus subtilis Smc protein and its two complex partners ScpA and ScpB in E. coli cells, and monitored effects on chromosome compaction by DNA staining of live cells using epifluorescence microscopy.

Data description: We show that expression of BsSmc leads to strong chromosome compaction, while expression of ScpAB does not show any effect. Chromosome compaction by Smc was also found for mutant versions lacking ATP binding or ability for head engagement, and was counteracted by concomitant expression of ScpAB. Our findings show that the SMC complex can act as autonomous condensation system in a heterologous bacterial host system, for which neither ATP binding nor ATP hydrolysis are required. Our investigation suggests that the negative effect on compaction activity of Smc exerted by ScpAB in vivo does not involve an effect on ATPase activity, but more likely a stabilization of the engagement of head domains, which in turn may affect ATPase activity.
\end{abstract}

Keywords: Structural maintenance of chromosomes, SMC, Bacillus subtilis, Chromosome condensation

\section{Objective}

Deletion of $s m c, s c p A$ or $s c p B$ genes in many bacteria, including $B$. subtilis, leads to slow, temperature sensitive growth, a defect in chromosome condensation/nucleoid compaction, and the generation of about $15 \%$ of cells lacking any chromosome (anucleate cells) [1-4]. Smc, ScpA and ScpB form a complex in vivo and in vitro [5, 6], and ScpA and ScpB form a sub-complex $[7,8]$ that affects ATPase activity of Smc [9]. Higher levels of Smc in B. subtilis cells result in chromosome hyper-compaction [7]. We wished to investigate if Smc and/or its complex partners ScpA and ScpB, which do not bind to DNA by

*Correspondence: graumanp@uni-marburg.de

2 SYNMIKRO, LOEWE-Zentrum Für Synthetische Mikrobiologie, Hans-

Meerwein-Straße, 35043 Marburg, Germany

Full list of author information is available at the end of the article themselves [10], can also condense chromosomes when expressed in other bacterial species. For this purpose, we chose $E$. coli cells as a model system, and employed a two-plasmids expression system. The PCR products of $s c p A$ and of $s c p B$ were cloned in tandem into pETDuet-1 (Novagen). $S m c$ was cloned into pCDFDuet-1 (Novagen). Mutants of $s m c$ were created by the QickChange-protocoll. $20 \mathrm{ml}$ culture of Rosetta 2 (DE3) pLysS cells hosting the desired vector was inoculated to an $\mathrm{OD}_{600}$ of 0.05 in LB containing required antibiotics and incubated on a shaking platform at $37{ }^{\circ} \mathrm{C}$ until $\mathrm{OD}_{600} 0.9$ was reached. Expression was induced with $0.5 \mathrm{mM}$ IPTG for Smc or Smc mutants, or with $3 \mathrm{mM}$ IPTG for ScpAB expression. We monitored expression via SDS-PAGE analyses (Fig. 1), and investigated changes in nucleoid morphology using epifluorescence microscopy and $20 \mu \mathrm{g} / \mathrm{ml}$

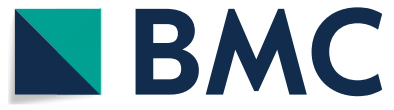

(c) The Author(s) 2020. This article is licensed under a Creative Commons Attribution 4.0 International License, which permits use, sharing, adaptation, distribution and reproduction in any medium or format, as long as you give appropriate credit to the original author(s) and the source, provide a link to the Creative Commons licence, and indicate if changes were made. The images or other third party material in this article are included in the article's Creative Commons licence, unless indicated otherwise in a credit line to the material. If material is not included in the article's Creative Commons licence and your intended use is not permitted by statutory regulation or exceeds the permitted use, you will need to obtain permission directly from the copyright holder. To view a copy of this licence, visit http://creativeco mmons.org/licenses/by/4.0/. The Creative Commons Public Domain Dedication waiver (http://creativecommons.org/publicdomain/ zero/1.0/) applies to the data made available in this article, unless otherwise stated in a credit line to the data. 
of DAPI to stain DNA, and $5 \mu \mathrm{g} / \mathrm{ml}$ of FM4-64 to stain membranes.

\section{Data description}

We set up low-level expression of Smc and/or high level for ScpAB in Escherichia coli cells, which have the highly diverged MukBEF complex instead of SMC/ScpAB [11]. Smc and mutant alleles were expressed for $60 \mathrm{~min}$ at similar levels (Fig. 1), and experiments were performed at least 3 times. Large E. coli cells cells $(>4 \mu \mathrm{m})$ contained a single bilobed nucleoid or two separated nucleoids, while small $(<3 \mu \mathrm{m})$ and middle-sized ( 3 to $4 \mu \mathrm{m})$ contained a single nucleoid (Fig. 2A). When ScpAB were expressed in the cells, no detectable change in nucleoid morphology could be detected (Fig. 2B). ScpAB were expressed at higher level than Smc or mutant Smc, also when expressed by themselves (Fig. 1), to rule out that effects generated by $\mathrm{Smc}$ are caused by simple protein overproduction. When wild type $\mathrm{Smc}$ was expressed in $E$. coli cells, chromosomes were markedly more compacted than in the absence of expression, or during expression of ScpAB (Fig. 2C, compare with 2A and 2B) with larger space between the nucleoid and the cell poles. Line scans through nucleoids in middle sized cells $(2.9-4.2 \mu \mathrm{m})$ expressing Smc showed markedly less DNA in the cell centre (Fig. 2J) than in control cells (Fig. 2H) or in cells expressing ScpAB (Fig. 2I), revealing that more middlesized cells contained two separated nucleoids than in the absence of Smc expression. Also, nucleoids were narrower during Smc expression, as seen by the different slope of the edges of the line scans (Fig. 2 J, compare with $2 \mathrm{H}$ ). Thus, Smc can hypercondense chromosomes in a heterologous cell system. When ScpAB were coexpressed with Smc, chromosomes were less condensed than during expression of Smc alone (Fig. 2D and $2 \mathrm{~K}$, compare with $2 \mathrm{C}$ and $2 \mathrm{~J}$ ) (Fig. $2 \mathrm{~J}$ ). These data suggest that in vivo, ScpAB down-regulate condensation activity of Smc in a heterologous cell system. Interestingly, overproduction of MukB in E. coli also leads to hypercondensation, but overexpression of MukB together with its two complex partners MukE and MukF leads to more pronounced compaction [12], indicating considerable differences between MukBEF and Smc/ScpAB systems.
Expression of ATP-binding and head-engagement Smc proteins led to hypercompaction of chromosomes, stronger than wild type $\mathrm{Smc}$ during the expression of ATP-binding mutant D1117A (Fig. 2E), or comparable to that of wild type Smc in case of head-engagement mutant S1090R (Fig. 2F), see corresponding line scans (Fig. 2L and $2 \mathrm{M}$ ). Co-expression of ScpAB with each mutant Smc counteracted the compaction activity (not shown). The line scan for mutant D1117A plus ScpAB (not shown) showed a profile similar to overexpression of Smc and ScpAB (Fig. 2K). These experiments show that ScpAB also affect condensation activity of ATP mutant Smc in vivo. According to current views, SMC proteins can extrude large DNA loops in an ATP dependent manner [13] and thereby compact chromosomes, and ScpA and ScpB lead to structural rearrangements between SMC head domains that directly affect ATP binding $[9,14]$.

A mutation next to the Walker B motif (E1118Q) deceases ATPase activity, and stimulates DNA binding in an ATP-dependent manner [6]. Expression of SmcE1118Q in E. coli cells led to a strong chromosome segregation defect, while cells were considerably elongated (Fig. 2G). Chromosomes showed a variety of shapes, from decondensed to hypercondensed, many were also stretched, and $19 \%$ of the cells showed a cut phenotype (chromosomes bisected by a division septum). In $25 \%$ of the cells the chromosome was unevenly located (Fig. 2G). Because of the uneven nucleoid localization, it did not make sense to generate line scans, but clearly, the E1118Q mutation blocks efficient chromosome segregation in E. coli, similar to its effect in B. subtilis [15], and has a very different phenotype than the other two ATP mutants.

\section{Limitations}

The B. subtilis SMC complex was expressed in wild type $E$. coli cells containing the endogenous MukBEF complex. We cannot rule out that the BsSMC complex has an effect on the activity of the MukBEF complex. We used an $E$. coli strain optimized for protein expression, so it is possible that other $E$. coli strains behave differently from the Rosetta strain employed. Because ScpAB were highly

Table 1 Overview of data files/data sets

\begin{tabular}{llll}
\hline Label & Name of data file/data set & File types (file extension) & Data repository and identifier (DOI or accession number) \\
\hline Data file 1 & Figure 1 & JPEG & figshare: https://doi.org/10.6084/m9.figshare.12681779.v3 [16] \\
Data file 2 & Figure 2 & TIF & figshare: \\
& & & https://doi.org/10.6084/m9.figshare.12681788.v4 [17] \\
\hline
\end{tabular}


overproduced, their effect on mutant Smc proteins may be different from a scenario with wild type protein copy numbers. We cannot address whether ATP binding or ADP and phosphate release may be affected by ScpAB.

\section{Abbreviations}

FM4-64: N-(3-triethylammoniumpropyl)-4-(6-(4-(diethylamino)phenyl)hexatrienyl) pyridinium dibromide; DAPI: 4',6-Diamidin-2-phenylindol (DAPI.

\section{Acknowledgements}

Not applicable.

\section{Authors' contributions}

TK performed all experiments. TK and PLG devised of the study and wrote the manuscript. Both authors read and approved the final manuscript.

\section{Funding}

Open Access funding enabled and organized by Projekt DEAL. This work was supported by the Deutsche Forschungsgemeinschaft (DFG).

\section{Availability of data and materials}

The data described in this Data note can be freely and openly accessed on [figshare] under https://doi.org/10.6084/m9.figshare.12681779.v3 (Fig. 1) [16] and https://doi.org/10.6084/m9.figshare.12681788.v4 (Fig. 2) [17]. Please see Table 1 for details and links to the data.

\section{Ethics approval and consent to participate}

Not applicable.

\section{Consent for publication}

Not applicable.

\section{Competing interests}

The authors declare no competing interests exist.

\section{Author details}

${ }^{1}$ Agilent Technologies R\&D and Marketing GmbH \& Co. KG, Hewlett-Packard-Strasse 8, 76337 Waldbronn, Germany. ${ }^{2}$ SYNMIKRO, LOEWE-Zentrum Für Synthetische Mikrobiologie, Hans-Meerwein-Straße, 35043 Marburg, Germany.

${ }^{3}$ Fachbereich Chemie, Hans-Meerwein-Straße 4, 35032 Marburg, Germany.

Received: 28 July 2020 Accepted: 16 October 2020

Published online: 11 November 2020

\section{References}

1. Niki H, Jaffe A, Imamura R, Ogura T, Hiraga S. The new gene mukB codes for a $177 \mathrm{kd}$ protein with coiled-coil domains involved in chromosome partitioning of E. coli. EMBO J. 1991;10(1):183-93.
2. Britton RA, Lin DC, Grossman AD. Characterization of a prokaryotic SMC protein involved in chromosome partitioning. Genes Dev. 1998;12(9):1254-9.

3. Graumann PL, Losick R, Strunnikov AV. Subcellular localization of Bacillus subtilis SMC, a protein involved in chromosome condensation and segregation. J Bacteriol. 1998;180(21):5749-55.

4. Moriya S, Tsujikawa E, Hassan AK, Asai K, Kodama T, Ogasawara N. A Bacillus subtilis gene-encoding protein homologous to eukaryotic SMC motor protein is necessary for chromosome partition. Mol Microbiol. 1998;29(1):179-87.

5. Mascarenhas J, Soppa J, Strunnikov AV, Graumann PL. Cell cycle-dependent localization of two novel prokaryotic chromosome segregation and condensation proteins in Bacillus subtilis that interact with SMC protein. EMBO J. 2002;21(12):3108-18.

6. Hirano M, Hirano T. Positive and negative regulation of SMC-DNA interactions by ATP and accessory proteins. EMBO J. 2004;23(13):2664-73.

7. Volkov A, Mascarenhas J, Andrei-Selmer C, Ulrich HD, Graumann PL. A prokaryotic condensin/cohesin-like complex can actively compact chromosomes from a single position on the nucleoid and binds to DNA as a ring-like structure. Mol Cell Biol. 2003;23(16):5638-50.

8. KleineBorgmann LA, Ries J, Ewers H, Ulbrich MH, Graumann PL. The bacterial SMC complex displays two distinct modes of interaction with the chromosome. Cell Rep. 2013;3(5):1483-92.

9. Kamada K, Miyata M, Hirano T. Molecular basis of SMC ATPase activation: role of internal structural changes of the regulatory subcomplexScpAB. Structure. 2013;21(4):581-94.

10. KleineBorgmann LA, Graumann PL. Structural maintenance of chromosome complex in bacteria. J Mol Microbiol Biotechnol. 2014;24(5-6):384-95.

11. Rybenkov W, Herrera V, Petrushenko ZM, Zhao H. MukBEF, a chromosomal organizer. J Mol Microbiol Biotechnol. 2014;24(5-6):371-83.

12. Wang Q, Mordukhova EA, Edwards AL, Rybenkov W. Chromosome condensation in the absence of the non-SMC subunits of MukBEF. J Bacteriol. 2006;188(12):4431-41.

13. Ganji M, Shaltiel IA, Bisht S, Kim E, Kalichava A, Haering CH, Dekker C. Real-time imaging of DNA loop extrusion by condensin. Science. 2018:360(6384):102-5.

14. Kamada K, Su'etsugu M, Takada H, Miyata M, Hirano T. Overall shapes of the SMC-ScpAB complex are determined by balance between constraint and relaxation of its structural parts. Structure 2017, 25(4):603-616 e604.

15. KleineBorgmann LA, Hummel H, Ulbrich MH, Graumann PL. SMC condensation centers in Bacillus subtilis are dynamic structures. J Bacteriol. 2013;195(10):2136-45.

16. Knust, T. \& Graumann, P.L. Fig 1. figshare. https://doi.org/https://doi. org/10.6084/m9.figshare.12681779.v3 (2020).

17. Knust, T. \& Graumann, P.L. Fig 2. figshare. https://doi.org/https://doi. org/10.6084/m9.figshare.12681788.v4 (2020).

\section{Publisher's Note}

Springer Nature remains neutral with regard to jurisdictional claims in published maps and institutional affiliations.

Ready to submit your research? Choose BMC and benefit from:

- fast, convenient online submission

- thorough peer review by experienced researchers in your field

- rapid publication on acceptance

- support for research data, including large and complex data types

- gold Open Access which fosters wider collaboration and increased citations

- maximum visibility for your research: over $100 \mathrm{M}$ website views per year

At BMC, research is always in progress.

Learn more biomedcentral.com/submissions 